\title{
Food from the forest of Java: tropical agro-forestry experiences in feeding dwellers and keeping the environment greener
}

\author{
Y. Widodo \\ Indonesian Legume and Tuber Crops Research Institute (ILETRI), \\ Indonesia
}

\begin{abstract}
Sixty percent of Indonesians live in Java, which in area is only around $7 \%$ of the country. As part of the global community, Indonesia has a strong endeavor to realize Millennium Development Goals (MDGs) which is put as a top priority to reduce hunger and alleviate poverty by $50 \%$ by 2015 . Unfortunately, the severity of global warming has locked a dream into a reality. Praxis of past and present food crops production in the forest area of Java indicates that Java is able to feed not only domestic dwellers, but also those in the outer islands and even abroad. Unfortunately, due to food crop production practices there is a detrimental effect to the forest, so its basic function as a carbon sink is disturbed. The forest area of Java is 3.3 million ha, only around $2.5 \%$ of the Indonesian forest area. Around $73 \%$ of the Java forest is managed by Perhutani (State Forest Enterprise), and the $27 \%$ remaining is maintained by civilians. Apart from cereal and grain, which is more recognized as a food source, shade tolerant root-crops have a significant advantage by their ability to produce more food in the form of starchy roots under a greener environment. Future progress of agro-forestry should be able to keep a greener forest as a carbon sink in line with providing food sufficiently for dwellers.

Keywords: food crops production, agro-forestry of Java, food adapts global warming.
\end{abstract}

\section{Introduction}

Entering into the third millennium, the voyage of humankind is entrapped into various predicaments that mainly can be grouped under four fundamental 
emergencies, explicitly that of sufficient food, of energy, water scarcity (FEWS) and ecological crisis [1]. Inappropriately, global climate change as a direct detrimental consequence from the global warming predicted is going to be a serious obstacle to meet food demand. Indeed, global warming was recognized more than 100 years ago, but the attention of the public to that problem began less than 25 years after the global community was experiencing the alteration of climate which was handicapping food production. The forest is considered as a main buffer to prevent the severity of climate alteration. MacDonald [2] based on a long series of experiments and experiences in Africa, stipulated that by agroforestry the desert widening phenomenon as well as hunger could be reduced. In line with food security for anticipating global warming, Indonesia has a rice based food pattern and has to prepare the implementation of food diversification program [3]. Indeed, from previous facts, during longer drought calamities when the reserve of rice and cereals was low, the community in rural remote areas went to the forest for gathering edible plants especially the vegetative portion of underground crops (root-crops), to be used as a source of carbohydrate to combat against hunger [4]. Drought severity and high temperature coinciding with global climate change are going to be rigorous problems for securing world rice production [5, 6]. Furthermore, Nguyen [6] also pointed out that slash and burn for cultivating upland rice, inducing or even triggering deforestation, will contribute to global warming due to the decrease of sink capacity to absorb $\mathrm{CO}_{2}$. Moreover, Neue [7] based on a series of experiments additionally revealed from wetland rice culture, that methane was released to the biosphere and this also had a major detrimental effect to global warming. The methane proportion of total greenhouse gases is around $15 \%$, while $\mathrm{CO}_{2}$ is around $55 \%$, but since methane can absorb heat latently, so methane emission is more dangerous, and consequently it should be reduced. It is predicted that $20 \%$ of methane in the biosphere is contribution from wetlands plus swamp rice culture. Therefore, in order to feed the increasing human population, rice cultivation needs an improvement in the new scheme of green revolution which is more ecologically orientated. On the other hand, exploring food other than rice as well as paradigm 'grain cereal mentality' and underground crops with a 'dirty image' [8] have to be re-determined in attempts to nourish the current and next generation under the world greener future.

From the thirteenth Conference of the Parties (COP-13) of the United Nation Framework Convention on Climate Change (UNFCCC) in Bali 3-14 December 2007 it was recommended that Reducing Emission from Deforestation and forest Degradation (REDD) was an appropriate way to prevent global warming [9]. As the second largest tropical forest country after Brazil, Indonesia makes a strong effort to maintain the forest by actively doing reforestation as well as by preventing deforestation and forest degradation. Geographically Indonesia is an archipelago whose islands are scattered throughout the equatorial line, therefore to control and maintain forest in those islands from illegal logging as well as wild squatters is really the problem. Moreover, the natural forest area conversion into industrial timber-forest production, estate plantation (oil palm, rubber, etc.), food crops agricultural land, settlement and related infrastructure are often 
threatening the ecological forest capacity as well as the livelihood of the native tribes living there [10]. Luckily from the REDD program organized by the World Bank supports the projects to strengthen and maintain the forest of Indonesia in three main large islands, namely Papua, Kalimantan and Sumatra [11]. The total forest area of Java is around 3,307,000 ha, but the total area of critical land in Java exceeds the forest area, namely 3,493,000 ha. It means that the forest area of Java is faced with a serious and dangerous situation. The critical damage of the forest in Java has been worsened by ecological catastrophes, the consequence of food famine, feed, fibers and fuel produced from the agricultural land area. To recover the forest and make them into a better condition and to provide food adequately, agro-forestry already practiced by communities in Java needs to be shared and scaled up based on forest sustainability.

\section{Methods and approaches}

To accomplish the objectives, there were three main activities indicating $3 \mathrm{D}$ stages conducted from 1995 up to currently, specifically:

\subsection{Discovery stage}

The discovery stage is aimed to gather information and identify as well as characterize facts from the field as well as data collection. Participatory rural appraisal (PRA) is used as a tool during the discovery stage. PRA was undertaken by a team staying in the communities living around the forest in different altitudes related to upper, middle watershed and coastal forest. These activities were carried out in the main source of the Brantas River in the central area of East Java located in between the mountain Anjasmoro and Welirang as well in the northern and western foot of Semeru volcano, as well as the eastern foot of Kawi mountain. According to Kompas [12] serious damage of the forest in Brantas upper watershed is $>60 \%$ due to conversion into vegetable cultivating areas. In actual fact, those sites are representing natural forest reserve areas in the upper watershed that is very important to sustain the source of water for the lower areas. In the middle watershed of Brantas, the forest area under the districts of Blitar, Tulungagung, Kediri, Jombang and Mojokerto were visited. Meanwhile, the forest in coastal ecology was gathered from Tuban, Lamongan as well as the western part of Pasuruan representing the north coast of Java, while the coastal forest in the south from several areas in Lumajang, Malang, Blitar, Tulungagung, Trenggalek till Pacitan have been surveyed. Secondary data including the number of unemployed, poor families and food security in household levels from the statistical bureau from Provincial and District level was collected before the team conducting PRA. Development progress in forest management by community and forest condition, number source of water, belief and religion and tradition as well as the pattern and role of the community in forest management, had been noted from the story told by the community. Strength Weakness Opportunity and Threat (SWOT) about the forest development progress and its prospect had been discussed during group discussion or small workshops between the PRA team and communities (stakeholders) in every site. 


\subsection{Development of participatory technology}

Development of findings from the discovery stages was used as a basic platform for improvement (modification) of the existing technology into appropriate technology with ecologically sustainably and economically feasible. Technology generation should be based on both aspect, not only feasible economical and socially acceptable aspects, but also from ecological characteristic that have to be beneficial and sustainable. Therefore, the species of trees incorporated into the forest should be selected from a different angle (not only timber), but for instance its fruits, its flowers or its leaves or gum (latex) etc can be harvested regularly without logging off the trees. The floor of the forest contains high organic matter, has a better friability of soil texture, and it is a suitable medium for growing underground (root and tuber) crops especially the family Araceae that are shade tolerant. Rapid growth and short duration harvest of edible biomass could also be provided from outside of spermatophyte such as thallophytic, bryophyte, pteridophyte and saprophytic plants non chlorophyll, such as various kinds of edible mushrooms. The media for rearing edible mushroom are primarily from the stems and branches senescence from the forest (not from a laceration of the main stem) and mixing with carbohydrate produced from starchy underground crops. High quality amino acid and protein could be provided from edible mushroom over a short period, so every 4-7 days farmers could be able to harvest and obtain an additional significant income. Chicken and small ruminants are also cultivated by utilizing space under the shade of trees (forest). Rearing of bees is also prospective as well as profitable to produce natural honey and facilitating the cultivation of plants naturally. Ponds can also be developed in between trees as hedgerow in order to conserve water for fishery as well as for preventing fire in the forest. Thus, forest fire disasters can be avoided especially during longer drought periods of the dry seasons. Aside from these endeavors by in situ food generation, the higher quality and nutritious foods are produced; organic matter from the waste of edible mushroom farming as well as animal waste, and fish-ponds sediment, could be utilized as fertilizer to sustain agriculture and forestry. Fuel (energy) from biogas was designed for processing human excretion and animal waste as well, so methane or reduction of $\mathrm{CO}_{2}$ emission could be attained. Those activities mentioned above are undertaken by participatory technology development (PTD) that is enriched by training and visits (TV) of the participant to other communities which have advance experience. A successful accomplishment in local action of the community with global impacts to reduce emission of $\mathrm{CO}_{2}$ under sustainable forest management needs support from the whole community in the wider regions. This tool for development is called EASIER (Empowering Agricultural Solution Initiatives for Economic Reconstruction) prepared by Widodo [4, 13] under ATAS (1995-2002) for educating hinterland tribes of Papua. The sites for development of appropriate technology are based on the results in the discovery stage using PRA. A prototype of mini forest had been installed in 0.75 ha of land under ATAS headquarter at Villa de Cerme Malang East Java, for training and multiplying the templates into various sites. 


\subsection{Dissemination stage}

Dissemination of appropriate technology is done to support sustainable forest management into wider communities across the region. Step wise dissemination is arranged to prepare distribution of information about new innovations by selecting audiences to work together under the solid inter-institution network for preventing global warming. Javanese and inhabitants of Java share a similar ability to act in response as a community, to cooperate hand in hand (gotong royong) for preventing global warming by increasing the sink capacity of $\mathrm{CO}_{2}$, if they have adequate understanding. This task was campaigned formally by government in line with several Non Government Organizations (NGOs) leaded by WALHI (Wahana Lingkungan Hidup Indonesia/Friends of the Earth Indonesia) which have patiently reminded and invited people to be aware about environmental problems and related aspects. Widodo [3] elucidated that traditionally Javanese are easy going and care for each other; therefore they are willing to share fairly about everything, especially important matters for the progressive and dynamics of livelihood under the formation of indigenous knowledge as a platform for sustainable development. Undeniably this tradition is an instrument with a fundamental and adequate strength for improving the critical condition of forest due to inappropriate direction in development. Aside from traditional institutions, Scouts Program (Pramuka) could be incorporated for disseminating appropriate technology to attain sustainable forest management because the Scouts Program is dealing with communities of various ages and educational background as well as occupations. Scouts Program also has very strong and solid organization for care of the forest as well as environmental activities. Dissemination in a form of sharing risk and profit by implementing technology developed was carried out in several sites of Central and West Java and Banten.

However, people from Kalimantan, Sumatra, Sulawesi, Nusatenggara West and East, Maluku as well as Papua, and even from Republic Democratic Timor Leste (RDTL) have also come to share experiences by staying several days under TV at the scheme of EASIER.

\section{Reasons behind the results}

\subsection{Forest of Java across historical perspective}

Unlike the forest in the outer three main islands that the international agency is interest in, the Java land area is only around $7 \%$, but it is occupied by $60 \%$ of the Indonesia citizens (Table 1), so sustainability of forest is under seriously critical threat. The total forest area of Indonesia is approximately 137,085,000 ha and Java contributes nearly $2.5 \%$ to this. The forest area of Java is $3,307,000$ ha consisting of 2.4 million ha managed by Perhutani and 0.907 million ha managed by citizens (Figure 1). Among those, the area of protection and conservation forest is only around 0.7 million ha (Table 2) and the remaining 2.6 million ha are production forest $[14,15]$. Among six provinces in Java, the largest forest is located in East Java and is approximately 1.3 million ha and 


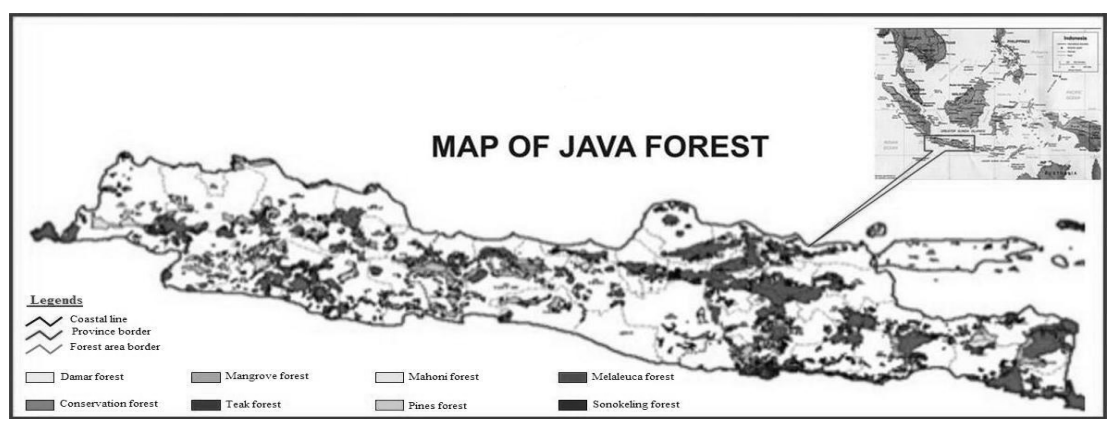

Figure 1: Distribution of various types of forest in Java.

Table 1: $\quad$ Population of Indonesia, Java dwellers and number of poor citizens in rural and urban areas, 2010.

\begin{tabular}{|c|c|c|c|}
\hline Country/Provinces & Population & $\begin{array}{c}\text { Number of poor citizens } \\
\text { in rural areas }\end{array}$ & $\begin{array}{c}\text { Number of poor citizens in } \\
\text { urban areas }\end{array}$ \\
\hline Total Indonesia & $237,556,363$ & $19,925,600$ & $11,097,800$ \\
\hline Banten & $10,644,030$ & 439,900 & 318,300 \\
\hline Jakarta & $9,588,198$ & - & 312,200 \\
\hline West Java & $43,021,826$ & $2,423,200$ & $2,350,500$ \\
\hline Central Java & $32,380,687$ & $3,110,200$ & $2,258,900$ \\
\hline Yogyakarta & $3,452,390$ & 268,900 & 308,400 \\
\hline East Java & $37,476,011$ & $3,655,800$ & $1,873,500$ \\
\hline Total Java & $136,563,142$ & $9,898,000$ & $7,421,800$ \\
\hline
\end{tabular}

Source: Data selected from BPS [15].

Table 2: $\quad$ Conservation forest area and percentage to total forest area of Java and Indonesia from 1981 to 2007.

\begin{tabular}{|c|c|c|c|c|c|c|}
\hline \multirow{2}{*}{ Years } & \multicolumn{2}{|c|}{$\begin{array}{c}\text { Conservation forest } \\
(1.000 \text { ha) }\end{array}$} & \multicolumn{2}{c|}{$\begin{array}{c}\text { Percentage to total } \\
\text { forest area }(\%)\end{array}$} & \multicolumn{2}{c|}{$\begin{array}{c}\text { Total forest area } \\
(1.000 \text { ha })\end{array}$} \\
\cline { 2 - 7 } & Java* & Indonesia & Java & Indonesia & Java & Indonesia \\
\hline 1981 & 718 & 30,345 & 21.71 & 26.83 & 3.307 & 113,077 \\
\hline 1984 & 718 & 30,316 & 21.71 & 26.72 & 3.307 & 113,433 \\
\hline 1990 & 718 & 29,649 & 21.71 & 26.53 & 3.307 & 111,775 \\
\hline $1999 * *$ & 425 & 33,520 & 18.47 & 29.86 & 2.300 & 112,274 \\
\hline 2001 & 425 & 29,037 & 18.47 & 30.60 & 2.300 & 94,894 \\
\hline 2004 & 718 & 31,685 & 21.71 & 23.18 & 3.307 & 136,710 \\
\hline 2007 & 718 & 31,604 & 21.71 & 23.05 & 3.307 & 137,090 \\
\hline
\end{tabular}

Note: *Data forest area of Java is collected from Perhutani. **During early reformation era illegal logging was very serious. Data selected different years from BPS [14]. 
contributes to around 30\% to the total forest area of Java. In the period of 19992005 illegal logging of forests in Java was very serious due to the economic crisis as well as the high demand of wood from furniture factories in response to world market demands. As a consequence, ecological catastrophes such as landslides, flooding during rainy season intermittent with drought disorders during dry season as well as heavy shoreline abrasion are the facts indicating and proving that the forest area of Java is really far away beyond sustainability.

Ecological catastrophes during rainy and dry seasons, primarily due to the damage of forest in Java, ultimately affect the agricultural land in producing food crops (Table 3). Undeniably, from the old traditional teaching, the overall objective of Javanese is that so called Memayu Hayuning Bawono with the intention of means to generate, trigger and stimulate (Memayu) the beautifulness (Hayuning) of the world (Bawono) nature (including biodiversity as well as a-biotic/physical elements) under harmony. This old traditional wisdom was performed in the various ritual ceremonies and daily livelihood from the prehistoric era (animism) till the last 1970, entering the third millennium this teaching and its practice was really ignored by most of community, except the local community such as Badui in Banten, Suku Naga in West Java, Samin in Central and East Java, Tengger and Osing in East Java as well as rural remote communities that still hold old traditions related to sustainable forest management.

Table 3: $\quad$ The main food crops produced from Java and Indonesia, 2010.

\begin{tabular}{|l|r|r|r|r|r|r|}
\hline \multirow{2}{*}{$\begin{array}{c}\text { Food } \\
\text { crops }\end{array}$} & \multicolumn{1}{|c|}{$\begin{array}{c}\text { Hava } \\
\text { Hrea (ha) }\end{array}$} & $\begin{array}{c}\text { Productivity } \\
\text { (t/ha) }\end{array}$ & Production (t) & $\begin{array}{c}\text { Harvest } \\
\text { area (ha) }\end{array}$ & $\begin{array}{c}\text { Productivity } \\
\text { (t/ha) }\end{array}$ & Production (t) \\
\cline { 2 - 7 } & $6,280,933$ & 5.73 & $35,995,608$ & $13,118,120$ & 5.030 & $65,980,670$ \\
\hline Rice & $2,157,424$ & 4.43 & $9,563,832$ & $4,133,785$ & 4.317 & $17,844,676$ \\
\hline $\begin{array}{l}\text { Soy } \\
\text { bean }\end{array}$ & 440,871 & 1.38 & 611,417 & 672,242 & 1.346 & 905,015 \\
\hline Peanut & 430,973 & 1.26 & 544,216 & 626,264 & 1.245 & 779,677 \\
\hline $\begin{array}{l}\text { Mung } \\
\text { bean }\end{array}$ & 165,500 & 1.16 & 192,902 & 284,564 & 1.137 & 323,518 \\
\hline Cassava & 570,387 & 17.82 & $10,165,726$ & $1,203,143$ & 19.194 & $23,093,522$ \\
\hline $\begin{array}{l}\text { Sweet } \\
\text { potato }\end{array}$ & 56,978 & 13.26 & 755,700 & 181,234 & 11.368 & $2,060,272$ \\
\hline
\end{tabular}

Source: Data selected from BPS [15].

To respect the soul of the forest (big trees habitat), from old traditional philosophy, teaches the community to provide various food regularly as so called caos dahar/sesaji. The foods which are specially prepared are left and then eaten by animals or the other living things in the forest. This kind of ceremony is still practiced regularly by Balinese, even today. From the history of Majapahit kingdom in East Java (1290-1400), the Balinese came from the Javanese who disallowed a new religion (Islam/Moslem from Arab) and still hold to Animism and Hinduism. This uniqueness of local wisdom is very important to be 
recognized by modern communities in order to generate the greener world future. As Javanese, in order to generate the harmony of the world they should understand Sastra Jendra Rahayuningrat Pangruwating Diyu, the means for attaining a glorious human being (Rahayuningrat), wisdom has to be achieved by learning knowledge and science (Sastra) under the name of God (Endra) and keep a distance far away (Pangruwating) from the greediness (Diyu). This indigenous knowledge needs revitalization and implementing urgently into modern life styles that presently tend to be consumptive and careless. Holistic approaches in sustainable forest management have to be undertaken in line with community development. Some endeavors related to livelihood for fulfilling the basic daily needs; especially that of food and fuel for the community that lives around the forest have to be installed for its security and safety. Government policy states that a gas tank of $3 \mathrm{~kg}$ must be available in every household in remote rural areas, but due to poor quality and often accidents due to tank trouble, firewood is still preferred to be used for preparing daily meals. Fuel (energy) for daily needs to prepare foods mostly using the small branches or senescence stems, also requires improvement in order to go along in line with sustainable forest management. Fortunately in agro-forestry, to provide firewood is not allowed by logging tree, but only cutting branches. By reducing the canopy of tree light interception the area under trees could be used for growing sun loving food crops such as grain and cereals, or major root-crops such as cassava and sweet potato. In the agro-forestry, with spacing of tree (forest) at $6 \times 1 \mathrm{~m}$, the branches are regularly cut for both purposes, to avoid or reduce the shading effect as well as providing firewood. The serious damage to forests in Java and Indonesia during the period of 1998 to 2005 is irreversible, so to get better such conditions needs more time and fortunately endeavor to immediately recover from what was started by implementing agro-forestry. Cereals and grain legumes, cassava and sweet potatoes as sun loving plants can be associated for agro-forestry with young trees, where shading is less than $30 \%$. Fortunately, when the shading effect increases to $80 \%$ root-crops from the family of Araceae, especially cocoyam (Xanthosoma sp), elephant foot yam (Amorphophallus sp) are still able to sequestrate $\mathrm{CO}_{2}$ to produce carbohydrate, protein, vitamin and minerals as well.

From the progress of root-crops under agro-forestry fully participatory managed by the community around the forest area, the global issues could be attained simultaneously. Adequate or even abundance of food can be harvested from root-crops without disturbing the role of forests to avoid the alteration of climate. By assuming 50\% of dry matter is carbon, in a periods of 6-12 months root-crops under agro-forestry are able to sequestrate carbon 3-7 t/ha. To anticipate future set-backs, shade tolerant root-crops with more nutritious, high productivity as well as with special traits have to be available easily for the community in order to supply the increase of demand of food and energy under greener circumstances. A mode to memorize that local wisdom or old tradition to respect trees had a similar mission with modern movement, so from a cognitive aspect this must be implemented further into effect and as a psychomotor for a future greener world. 


\subsection{Praxis learnt for future improvement}

The critical condition of Java forests is due mainly to over exploitation. From the coastal region, the mangrove forest which is very useful to provide a suitable environment for fish and shrimp nurseries is still conflicted with daily needs as a source of firewood and construction material. Luckily in Tuban, Lamongan, Gresik and the Pasuruan communities in coastal areas the communities are aware about the function of mangrove. Recently in several coastal areas of East Java, particular reforestation with the emphasis on mangrove was done by communities, supported by companies as well as profit institutions through Corporate Social Responsibility (CSR). Reforestation and forestations were done mainly at the early part of the rainy season through CSR or by the community due to the increase of awareness. In high altitudes, at the source of water, arboretums are intensively recovered by local communities. Facts indicate that steep slopes are utilized for growing vegetables such as potato, cabbage etc (in higher altitudes) or food crops like maize, upland rice or cassava (in lower altitudes), yet in the near future such situation will change by growing more trees in the area (Table 4). Current trends revealed the price of fast growing tree species Albizia sp. Acacia sp. was economically better, but the increase of awareness of ecology will reject logging of tree, thus tree species producing fruit

Table 4: $\quad$ Food, feed and fuel generated from agro-forestry in various sites of Java.

\begin{tabular}{|c|c|c|c|c|c|c|}
\hline Food crops & $\begin{array}{c}\text { Main forest and } \\
\text { space }(\mathrm{m})\end{array}$ & $\begin{array}{c}\text { Shade } \\
\text { intensity } \\
(\%)\end{array}$ & $\begin{array}{l}\text { Yield } \\
(\mathrm{t} / \mathrm{ha})\end{array}$ & $\begin{array}{l}\text { Forage for } \\
\text { feed or } \\
\text { firewood }\end{array}$ & $\begin{array}{l}\text { Bio-ethanol } \\
\text { conversion }\end{array}$ & $\begin{array}{l}\text { Site and year } \\
\text { measurement }\end{array}$ \\
\hline Upland rice & Teak $6 x 1$ & $25-40$ & 2.25 & 4.30 & $\begin{array}{c}\text { Not } \\
\text { allow }\end{array}$ & Cianjur, 2009 \\
\hline Maize & Mahoni $3 \times 2$ & $30-42$ & 3.38 & 7.12 & $2.5: 1$ & Blitar, 2008 \\
\hline $\begin{array}{c}\text { Sweet } \\
\text { sorghum }\end{array}$ & $\begin{array}{l}\text { Melaleuca } \\
4 \times 1\end{array}$ & $10-15$ & 4.17 & 8.55 & $2.5: 1$ & $\begin{array}{l}\text { Mojokerto, } \\
2008\end{array}$ \\
\hline Soybean & Teak 6x1 & $20-30$ & 1.36 & 2.49 & - & Nganjuk, 2009 \\
\hline Mungbean & Teak 6x1 & $20-30$ & 1.18 & 1.95 & - & Saradan, 2009 \\
\hline Cowpea & Mindi $3 \times 2$ & $25-40$ & 1.29 & 2.90 & - & Subang, 2009 \\
\hline Pigeon pea & Mindi $3 \times 2$ & $25-40$ & 1.20 & 2.66 & - & Subang, 2009 \\
\hline Cassava & Teak $6 \times 1$ & $15-25$ & 37.52 & 26.23 & $6: 1$ & $\begin{array}{c}\text { Indramayu \& } \\
\text { Pati, } 2009\end{array}$ \\
\hline Sweet potato & Mahoni 6x1 & $10-20$ & 26.40 & 12.15 & $8: 1$ & Blitar, 2008 \\
\hline Arrow root & Albizia $2 \times 2$ & $30-50$ & 12.27 & 2.78 & $7: 1$ & Blitar, 2008 \\
\hline Cana root & Teak $3 \times 2$ & $25-40$ & 16.45 & 3.17 & $7: 1$ & Blitar, 2008 \\
\hline Yam & Albizia $2 \times 2$ & $30-50$ & 27.59 & 7.42 & $6: 1$ & Tuban, 2009 \\
\hline Cocoyam & Albizia $2 \times 2$ & $30-60$ & 29.16 & 4.23 & $6: 1$ & $\begin{array}{c}\text { Banyuwangi, } \\
2008\end{array}$ \\
\hline Taro & Mahoni 3x2 & $30-40$ & 21.05 & 2.34 & $6: 1$ & Pasuruan, 2009 \\
\hline $\begin{array}{c}\text { Elephant food } \\
\text { yam }\end{array}$ & Teak $3 \times 2$ & $40-65$ & 19.24 & 2.27 & $6: 1$ & Madiun, 2010 \\
\hline
\end{tabular}

Note: Food crops associated under agro-forestry is conducted by communities around the forest area. In densely areas, each household only manages 0.25 ha under the forest. 
such as breadfruit, jackfruit etc will be more preferred than other species. Moreover in the land area outside of forest, especially nearby cities or industrial estates, due to the wages of agricultural labor tending to be too expensive, growing trees that imitate a mini forest is an alternative source of income mainly for timber. Food sovereignty produced and consumed locally is also important perspective to attain economic feasibility as well as ecological benefit. Retrieval of food production which is ecologically friendly under the shade of forest requires verification and validation before recommended into larger areas across the region for the wider community. While root-crops, edible mushroom (saprophytic plants) are important sources of carbohydrate, protein, fat, vitamins plus minerals that can be cultivated under the entirely shade of forest without disturbing the forest, sadly food patterns show most of the dweller in Java still based on rice and cereals (Table 5).

Flach and Rumawas [16] elucidated under the family Aracea particularly in two genera, namely Amorphophallus and Xanthosoma have the prerequisite to foresee global climate change under REDD, because these two genera are shade tolerant crops with a reasonable yield of edible portion. Unlike cassava and sweet potato, both genera are still grown under subsistence for supporting

Table 5: Average consumption of calorie and protein per capita/day from various food sources from 1999 to 2009 .

\begin{tabular}{|c|c|c|c|c|c|c|c|}
\multicolumn{2}{c}{} & Calorie & \multicolumn{1}{l}{} & Protein & \multirow{2}{*}{ No. } \\
& Commodities & 1999 & 2005 & 2009 & 1999 & 2005 & 2009 \\
\hline 1 & Cereals & $1,066.50$ & $1,009.13$ & 939.99 & 25.04 & 23.69 & 22.06 \\
\hline 2 & $\begin{array}{c}\text { Root and tuber } \\
\text { crops }\end{array}$ & 60.73 & 56.01 & 39.97 & 0.43 & 0.45 & 0.33 \\
\hline 3 & Fish & 36.04 & 47.59 & 43.52 & 6.07 & 8.02 & 7.28 \\
\hline 4 & Meat & 20.07 & 41.45 & 35.72 & 1.33 & 2.61 & 2.22 \\
\hline 5 & Eggs and milk & 24.39 & 47.17 & 51.59 & 1.43 & 2.71 & 2.96 \\
\hline 6 & Vegetables & 32.28 & 38.72 & 38.95 & 2.23 & 2.52 & 2.58 \\
\hline 7 & $\begin{array}{c}\text { Grain legumes } \\
\text { /beans }\end{array}$ & 52.4 & 69.97 & 55.94 & 4.81 & 6.31 & 5.19 \\
\hline 8 & Fruits & 32.71 & 39.85 & 39.04 & 0.33 & 0.43 & 0.41 \\
\hline 9 & Oil and fat & 205.9 & 241.87 & 228.35 & 0.42 & 0.48 & 0.34 \\
\hline 10 & Beverages & 103.35 & 110.73 & 101.73 & 0.79 & 1.08 & 0.98 \\
\hline 11 & Spices & 15.42 & 19.25 & 15.61 & 0.66 & 0.82 & 0.68 \\
\hline 12 & Miscellaneous & 28.76 & 52.84 & 58.75 & 0.53 & 1.03 & 1.21 \\
\hline 13 & Fast food & 170.78 & 233.08 & 278.46 & 4.62 & 6.44 & 8.1 \\
\hline 14 & $\begin{array}{c}\text { Alcoholic } \\
\text { beverages }\end{array}$ & 0.04 & - & - & 0 & - & - \\
\hline 15 & $\begin{array}{c}\text { Tobacco and } \\
\text { pepper }\end{array}$ & 0 & 0 & 0 & 0 & 0 & 0 \\
\hline & Total & $1,849.36$ & $2,007.65$ & $1,927.63$ & 48.67 & 55.27 & 54.35 \\
\hline
\end{tabular}

Source: Data selected and calculated from BPS [14, 15]. 
a traditional livelihood $[17,18]$. Although its biological potential to produce edible food is more than twofold over cereals and legumes, however both genera remain neglected, they never received comparable scientific, industrial and commercial attention.

Consequently, the distributions as well as its ethno-botanical information of these two genera are not adequately available from statistical data. Agro-forestry is the future answer for bio-economic style that should be prepared and improved from now by incorporating logical, ethical and esthetical framework as well as in the continuum of ontological, epistemological and axiological steps. Future expectation of community in forest management to sustain the natural resource had been formulated into real proposal and conveyed to local government as well as Perhutani who formally has authority to manage the forest state from risk [19, 20]. It is expected in areas that although previously used as production forest for producing timber, due to being the source of water, they must be conserved as sustainable or using the area under a steep slope. Those areas must be kept rigorously as protection or conservation forest.

\section{Concluding remarks}

Food made sufficiently available from a forest is not a dream, but it is a reality and needs to be implemented into the larger domain for adaptation and mitigation against global warming. Shade tolerant root-crops, such as arrow root, cocoyam, taro and elephant foot yam are appropriate food crops to be incorporated under the shade of forest without logging and lacerating branches. Carbohydrate produces from underground crops aside for direct consumption, could be used as a starter for producing protein, vitamin and minerals by nurturing mushroom, fish or small ruminants and chicken. Beautiful organic farming can be implemented under agro-forestry by integrating shade tolerant root crops, animal husbandry, fish; interaction for feeding dwellers sufficiently and keeping a greener environmental for the benefit of many.

\section{Acknowledgements}

Deep gratitude goes to Perhutani and ATAS Foundation that makes it possible for the author to accomplish field work as well as to present a paper in the Food and Environment Summit 2011.

\section{References}

[1] Eco Summit. Beijing Eco Declaration Draft. Ecological Complexity and Sustainability: Challenges and Opportunities for 21th Century's Ecology. 4p. 2007.

[2] MacDonald, L.H. Agro-forestry in the Africa Humid Tropics. Proc. of a Workshop held in Ibadan Nigeria. 27 April - 1 May 1981. The United Nations University. 171p. 1982.

[3] Widodo, Y. Sweet potato cultivation in a rice-based farming system: the dynamics of indigenous knowledge. In Jurg Schneider (Ed.) Proc. of an 
International Workshop on Indigenous Knowledge in Conservation of Crop Genetic Resources. Cisarua Bogor January 30 February 3, 1995. CIPCRIFC. Pp105-114. 1995.

[4] Widodo, Y. Produce more food from the starchy roots, a strategy for feeding the people against the economic crisis. Paper submitted to ATAS Foundation for discussion with NGOs under scheme of EASIER (Empowering Agricultural Solution Initiative for Economic Reconstruction). 10 p. 1999.

[5] International Rice Research Institute/IRRI (2009, October 19). Climate Change Threatens Rice Production. Science Daily. Retrieved October 12, 2010, from http://www.sciencedaily.com/releases/2009/10/ 091016094049.htm

[6] Nguyen, N.V. Global Climate Change and Rice Food Security. Executive Secretary, International Rice Commission Food and Agriculture Organization (FAO). Rome. Pp24-30. ww.fao.org/rice/global climate (downloaded December 28, 2008).

[7] Neue, H.U. Methane emission from rice fields: wetland rice fields make a major contribution in global warming. Bioscience 43(7):466-73. 1993.

[8] Rhoades R.E., and D. Horton. Past civilization, present world needs, and future potential: Rootcrop agriculture across the ages. In R.H. Howeler (Ed.) Proc. 8th Symp. of Int. Soc. for Trop. Root Crops. (ISTRC) Oct. 30Nov. 5, 1988. Bangkok, Thailand. Pp 8-19. 1990.

[9] United Nations Framework Convention on Climate Change (UNFCCC). Reduction Emission from Deforestation and forest Degradation (REDD): A recommendation from Bali Road Map. www.unfccc.org (downloaded February 10, 2009).

[10] Stanford University (2007, May 7). Climate Change Threatens Indonesian Agriculture, Study Says. Science Daily. Retrieved October 12, 2010, http://www.sciencedaily.com /releases/2007/05/070502094444.htm

[11] Carbon Initiative World Bank. Carbon Initiative Help Desk World Bank. www. world bank. org. An answer of email from committee to yudi_atas@yahoo.com. 2009.

[12] Kompas. Lingkungan Hutan Jatim berkurang 63 persen (Environment. East Java Forest area reduced 63 percent). p 23. Harian Pagi Kompas, Wednesday February 11, 2009.

[13] Widodo, Y. Anticipating food and energy supply from rootcrops under various ecological complexity. Paper presented in the Eco Summit 2007. Jiuhua Beijing, 22-27 May. 14 p. 2007.

[14] BPS. Statistik Indonesia. Statistic Indonesia. Statistical Year Book of Indonesia 1981 to 2008. Badan Pusat Statistik Jakarta Indonesia. Book version 1982-2009.

[15] BPS. Statistik Indonesia. Statistic Indonesia. www.bps.go.id. 2010.

[16] Flach, M and Rumawas, F. (Eds.). PROSEA Plant Resources of South-East Asia No 9. Plants yielding non-seed carbohydrate. Backhuys Publishers, Leiden. 237p. 1996. 
[17] Jansen, P.C.M., C. van der Wilk and W.L.A. Hetterscheid. Amorphophallus Blume ex Decaisne. In Flach, M and Rumawas, F. (Eds.). PROSEA Plant Resources of South-East Asia No 9. Plants yielding non-seed carbohydrate. Backhuys Publishers, Leiden. pp 45-50. 1996.

[18] Jansen, P.C.M and V. Premchand. Xanthosoma Schott. In Flach, M and Rumawas, F. (Eds.). PROSEA Plant Resources of South-East Asia No 9. Plants yielding non-seed carbohydrate. Backhuys Publishers, Leiden. pp 159-164. 1996.

[19] United Nations. The Millennium Development Goals Report. End Poverty Millennium Development Goals 2015, Make it Happen. 56p. 2008.

[20] World Wildlife Fund/ WWF (2007, December 3). Indonesia At Risk: Climate Change Threatens People And Nature. Science Daily. Retrieved October 12, 2010, from http://www.sciencedaily.com/releases/2007/11 /071130170615.htm 